\title{
The Contribution of Leg Power to the Long Jump Capability UKM Students Sport
}

\author{
Alimuddin \\ Faculty of Sports Sciences, Universitas Negeri Padang, Padang, Indonesia \\ *Corresponding author: Email, alimuddin@fik.unp.ac.id
}

\begin{abstract}
Long jump is one of the athletic sports. Indonesian's current athletics events have gradually shown a very satisfying appearance. In recent years, sports in this athletic branch have been able to compete with Asian countries, especially in Southeast Asia. However, there are several Indonesian athletic sports that have not been able to demonstrate the best performance in the International. This is due to lack of concern or the branch. Long jumping sports for example that until now we rarely hear to donate the gold medal to Indonesian at big events. The purpose of this study is to find out one of the contributions of physical capability explosive power of the limbs againts the ability of jumps. The type of research conducted is simple experimental research. Sample of this study are saturated samples with reference to nonprobability sampling techniques. The test performed is a remote jump test with no prefix. Analysis of the data carried out is quantitative descriptive analysis. Based on the result of a single regression calculation of 15 people samples, obtaind $\beta=0707$, with a value of Tcount $(\mathrm{t} 0)=3.603$ and $\rho=0.000,(\rho<0.05)$ menas there is a significant contribution to the explosive power of the limbs againts the ability of the long jump in UKM students sports. Thus, if a student has a good explosive power will be followed by a distant jumping ability.
\end{abstract}

Keywords: Long jump, explosive power

\section{INTRODUCTION}

Sports achievement is a sport that must have special capabilities to be the best. In addition, the physical freshness is also very related to maintenance in doing a physical activity. Someone needs great physical activity to be the basis of one's ability for daily activities. Some branches of exercise as a peculiary or in other words that are often used as a race or match is very much from individual to the sake. The most popular sports branch of this is soccer sport, but actually many other morals are more potentially a more important scholar branch in the world of specials in Indonesia such as athletic sports.

Long jumpt sport is a sport that requires all people or athletes that do it have a special ability.Long jump sport is not as easy as what we might see on its implementation. This sport-branch also has special techniques to do so. Many people have done it, but the result of the forecast is expected to inevitable in reality. Long jumped divided into several phases, prefix, reth, and hovers [1]. The most important stage of the phase of the repetition is the second stage of a series of movements in the branch of the long jump. The goal is to change the movement of a run into a jump, by doing a leap perpendicularly while maintaining the horizontal speed as much as possible [2].

\section{METHODS}

The research conducted is a simple experimental study with each one free variable and dependent variable. The sample in this study is a student of sports activities unit. Sampling in this study refers to the sampling technique that is non-existent nonprobability that is saturated samples which is a sample determination technique when all population members are used as samples. The method used in data collection is to record the test results given to the sample. The test is done with the long jump test without a prefix [3]. The best leaf score of 3 times the opportunity is recorded as the final result. The analysis used is descriptive statistical analysis that includes the average calculation or mean, median, mode and standard deviation. Furthermore, will be reached in the analysis of this research data after the descriptive test is the data regression test to prove the contribution of the expense of the led power on the ability to the long jump.

\section{RESULT AND DISCUSSION}

\section{A. Result}

Lip data of led power is obtained through a long jump test without a prefix. To know the level of contribution of the led power to the ability of long 
jumped by a single regression analysis with the summary of the analysis of the following:

Table 1. Regression analysis results

\begin{tabular}{|l|l|l|l|l|}
\hline Variabel & B & $\mathbf{t}_{\mathbf{0}}$ & $\mathbf{P}$ & Ket. \\
\hline $\begin{array}{l}\text { DYLDTK (X) } \\
\text { KLJH (Y) }\end{array}$ & 0.707 & 3.603 & 0.000 & Signifikan \\
\hline
\end{tabular}

Based on the above table appear that the result of single regression calculation, obtained $\beta=0.707$, with the value of $t$ count $(\mathrm{T} 0)=3.603(\rho<0.05)$, Because the probability $(\rho)=0.000$ is much smaller than $(\alpha)=0.005$, then $\mathrm{H} \_\mathrm{O}$ is rejected and $\mathrm{H} \_1$ is accepted, there is a significant contribution of led power to the ability to jump away on a students UKM sport

\section{B. Discussion}

Proven from the results of the analysis $(\rho<0.05)$ or Ho rejected and $\mathrm{H} 1$ received, then the obtained results if associated with the framework and the underlying theories, basically the results of this study support the existing theory

The results of this analysis can be explained that the explosive contributes to the ability of the jump far by $50.00 \%$. The same remains $50.00 \%$ described by other variables that are not observed in this study. This can be explained that if students UKM sport of UNM have unnoly goods lending goods can make a long jump with the efficiency of the energy issued.

Lip's expense power is the ability of muscles to overcome very fast contraction. Liptic power is lengths to the dominant sports branches using limbs, it can perform a leap movement with maximum strength with businesses deployed in the shortest time. Changes in advance movements into a restive movement should be done by providing maximum power on the tie legs. This means that at the time of the foot rely in need of explosive power to bring the body floating in the air without eliminating the direction of horizontal motion. So the explosive power has an important role in doing long jumps.

Leg power is very important for sports branches that are dominant using the legs, so they can do the leap with maximum strength with the effort exerted in the shortest possible time. Changing the forward movement to the resting movement must be done by giving maximum strength to the supporting foot. This means that when the feet are fully in need of explosive power to bring the body to float in the air without losing the horizontal direction of motion. So that the explosive power has an important role in doing the long jump.

\section{CONCLUSION}

Based on the results of research and testing conducted so that it can be concluded that there is a significant contribution between led explosive towers ability of long jump students of sports activities unit.

\section{REFERENCES}

[1] Sidik Zafar Dikdik. 2010. Mengajar dan Melatih Atletik. Remaja Rosdakarya: Bandung.

[2] Jarver Jess. 2012. Belajar dan Berlatih Atletik. Pionir Jaya: Bandung.

[3] Nur Ichsan Halim. 2011. Tes dan Pengukuran Kebugaran Jasmani. Badan Penerbit UNM; Makassar 